\title{
CADOProSys Software. Process selection
}

\author{
Catrina Chivu*, Cătălin-Iulian Chivu, and Cristina Găvruş \\ Transilvania University of Braşov, Department of Engineering and Industrial Management, Mihai \\ Viteazul 5, Braşov, Romania
}

\begin{abstract}
CADOProSys was developed by a group of teachers from Engineering and Industrial Management Department of Transilvania University of Brasov-Romania. Present paper is focused on module design for process selection that allows undergraduates to choose the appropriate technology based on product's specification, to obtain route sheets. Based on these route sheets the users will be able to determine the equipment requirements, materials requirements (type and quantity), standard times (computed based on theory or estimated based on firm's standards), and layout requirements. The Process selection module is interconnected with logistic module (sub-modules oriented on suppliers selection and facility layout design).
\end{abstract}

\section{Introduction}

In a business plan, designing and planning the new production system is one of the most important parts of the start-up.

Today, on the market, there is a lot of ERP (Enterprise Resource Planning) software, focused on company's management. These packages offer management for both discrete and repetitive manufactures in the automotive. There are managed accounting, business analytics human resources, inventory control, invoicing, quality control \& inspection, supply chain, repair \& maintenance, etc. Each of this software may be used for complete enterprise resource planning and manufacturing execution functionality including generating shipping labels and packing slips and then tracks shipments online to multiple shipping addresses [1]. Thus, there is software for assembly process simulation (e.g. DELMIA) [2]. One of the most powerful and complex instrument is offered by Siemens, through Tecnomatix software [3]. This software allows designing innovative systems based on product engineering, manufacturing engineering and production. It is a very complex instrument that may be used to increase productivity through planning and to manage manufacturing by optimising subsystems. The most disadvantageous aspect of this product is the complexity, which make it usable only by specialists, not beginners in the field of manufacturing system design.

Analysing the market's offer it can be underlined that a few of such software are oriented on designing a manufacturing system, and less than that for teaching future engineers what are the rules that they should follow when they need to design new system or modernize an existing one (Figure 1).

* Corresponding author: catrina.c@unitbv.ro 


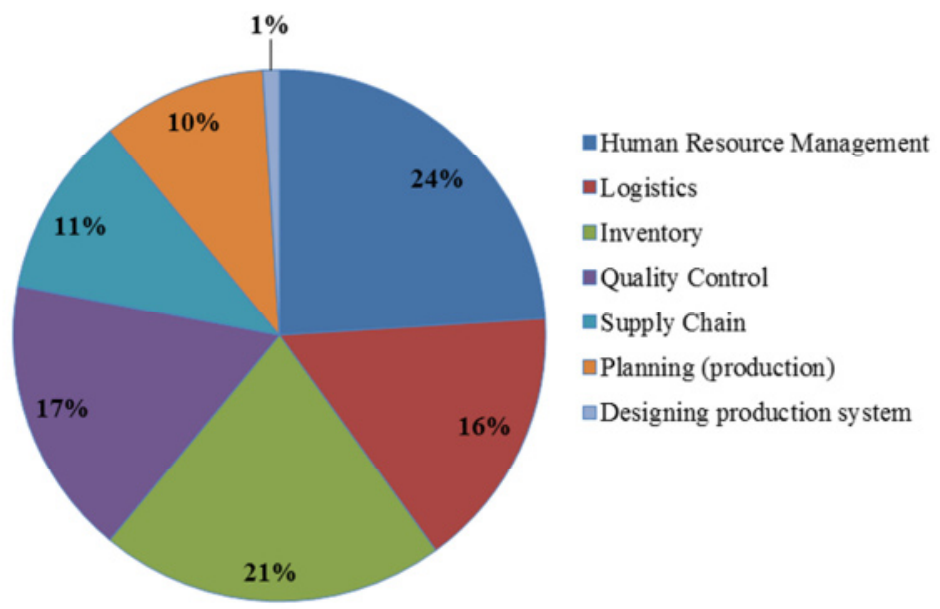

Fig. 1. Manufacturing software, based on field of interest (processed data from [1]).

\section{CADOProSys. Manufacturing design module}

\subsection{General concept}

Product and service choices, capacity planning, process selection, and layout of facilities are among the most basic decisions because they have long-term consequences for business organizations.

The impact of process selection goes beyond operations management, affecting entire organization and its ability to achieve its mission. So process selection choices very often have strategic significance. Different process types have different capacity ranges, and once a process type is functioning, changing it can be difficult, time consuming, and costly.

Table 1. Process types [4].

\begin{tabular}{|l|l|l|l|l|l|}
\cline { 2 - 6 } \multicolumn{1}{c|}{} & \multicolumn{1}{c|}{ Job Shop } & \multicolumn{1}{c|}{ Batch } & $\begin{array}{l}\text { Repetitive/ } \\
\text { Assembly }\end{array}$ & \multicolumn{1}{|c|}{ Continuous } & \multicolumn{1}{|c|}{ Project } \\
\hline Description & $\begin{array}{l}\text { Customized } \\
\text { products }\end{array}$ & $\begin{array}{l}\text { Semi- } \\
\text { standardized } \\
\text { products }\end{array}$ & $\begin{array}{l}\text { Standardized } \\
\text { Products }\end{array}$ & $\begin{array}{l}\text { Highly } \\
\text { standardized } \\
\text { products }\end{array}$ & $\begin{array}{l}\text { Nonrepetitive } \\
\text { set of } \\
\text { activities }\end{array}$ \\
\hline \multirow{5}{*}{ Advantages } & $\begin{array}{l}\text { wide variety } \\
\text { of work }\end{array}$ & $\begin{array}{l}\text { flexibility; } \\
\text { easy to add or } \\
\text { change } \\
\text { products }\end{array}$ & $\begin{array}{l}\text { Low unit } \\
\text { cost, high } \\
\text { volume, } \\
\text { efficient }\end{array}$ & $\begin{array}{l}\text { Very } \\
\text { efficient, very } \\
\text { high volume }\end{array}$ & $\begin{array}{l}\text { Competiti- } \\
\text { veness on } \\
\text { market, } \\
\text { variety of } \\
\text { work }\end{array}$ \\
\hline & $\begin{array}{l}\text { Slow, high } \\
\text { cost per unit, } \\
\text { complex } \\
\text { planning and } \\
\text { scheduling }\end{array}$ & $\begin{array}{l}\text { Moderate cost } \\
\text { per unit, } \\
\text { moderate } \\
\text { scheduling } \\
\text { complexity }\end{array}$ & $\begin{array}{l}\text { Low } \\
\text { flexibility, } \\
\text { high cost of } \\
\text { downtime }\end{array}$ & $\begin{array}{l}\text { Very rigid, } \\
\text { lack of } \\
\text { variety, costly } \\
\text { to change, } \\
\text { very high cost } \\
\text { of downtime }\end{array}$ & $\begin{array}{l}\text { High cost per } \\
\text { unit, complex } \\
\text { planning, } \\
\text { high variety } \\
\text { of equipment } \\
\text { and skills for } \\
\text { employees }\end{array}$ \\
\hline
\end{tabular}

Obviously, long-term forecasts as well as an organization's mission and goals are important in developing a process strategy [4]. Process selection defines the strategy of the 
firm, having impact on capital intensity and process flexibility, an appropriate selection affecting directly facility and equipment choices, layout, and work design.

Before starting process selection it should be considering desired: variety in products, flexibility of equipment and volume output.

There are five basic process types: job shop, batch, repetitive, continuous, and project (Table 1).

To operate effectively, a manufacturing firm must have systems that allow it to efficiently accomplish its type of production. Production systems can be divided into two categories: (1) production facilities and (2) manufacturing support systems. Production facilities refer to the physical equipment and the arrangement of equipment in the factory. Manufacturing support systems are the procedures used by the company to manage production and solve the technical and logistics problems encountered in ordering materials, moving work through the factory, and ensuring that products meet quality standards [5].

To design educational software focused on production system, it should be considered both types of manufacturing operations: processing operations and assembly operations. It also should be included both stages of system: new production system or an existing one.

CADOProSys Software was developed based on the production systems design principles and correlated with QFD (Quality Function Development) chart. Software allows the students to both design new production systems and develop an existing system through implementing new product, or increasing the production [6, 8-12].

Each module is a combination of requirements and results that interconnect to other module or direct with the conclusion page. Because CADOProSys Software is an educational one, after each selection done by students are synthetized the generated restrictions.

\subsection{Module design}

CADOProsSys module oriented on manufacturing the product has, as main goal, to obtain the route sheets, one sheet per part. The outputs of the manufacturing module will be used in the logistics module: to select de suppliers, to design the facility, to select employees.

CADOProSys is educational software, thus, almost all selections done in each step is followed by some theoretical details regarding the selection, with rules, data required to resolve de problem.

A typical route sheet contains the following information [7]:

1. Heading of Route Sheet:

- component name and part identification;

- drawing reference number;

- lot size

2. Body of Route Sheet:

- operational sequences;

- equipment requirements;

- standard times;

- machine capacity/ hour;

- material requirements (type and quantity)

The general logic diagram of the module (Figure 2) is, in fact, the diagram of the steps mandatory in selecting of manufacturing processes. 


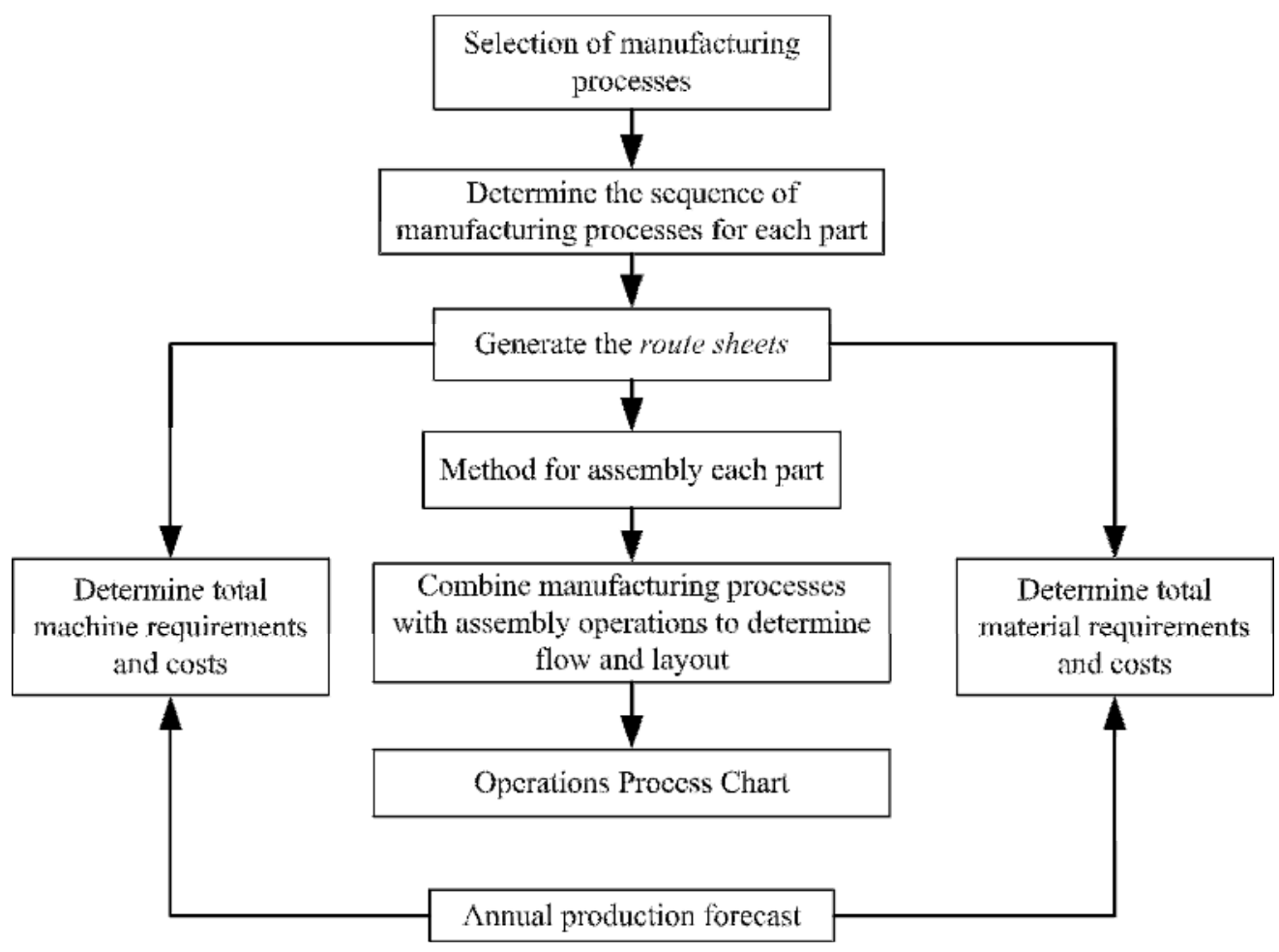

Fig. 2. Logic diagram of the module.

Thus the input data, grouped on stages of manufacturing are presented in Table 2.

Table 2. Input data.

\begin{tabular}{|l|l|}
\hline Steps & \multicolumn{1}{c|}{ Input data } \\
\hline Product analysis & $\begin{array}{l}\text { parts list; assembly drawings/ part drawings; assembly chart } \\
\text { (some of the activities are only if manufacturing process is an } \\
\text { assembly one) }\end{array}$ \\
\hline Manufacturing process & $\begin{array}{l}\text { - manufacturing the type: changing shape/ machining part to fixed } \\
\text { dimension/ obtaining a surface finish/ joining parts or materials/ } \\
\text { changing physical properties; } \\
\text { - machine cost database; } \\
\text { - material costs database }\end{array}$ \\
\hline Route sheet & $\begin{array}{l}\text { part name and code; drawing reference; lot size; operation code; } \\
\text { operation description; jigs, fixtures, tools; machine type. }\end{array}$ \\
\hline
\end{tabular}

In the present paper there are shown the steps and software facilities in the case of an existing manufacturing system (Figure 3), with continuous process (Figure 4).

According to the manufacturing process's type, the interface will ask for input data and explain requirements (according to Table 2). Machine and material costs database are automatically generated at the end of the suppliers' module of CADOProSys software. The end of that module gives also the space required for each device, equipment of machinetools, according to the technical data sheets, information used in layout module of the software. 


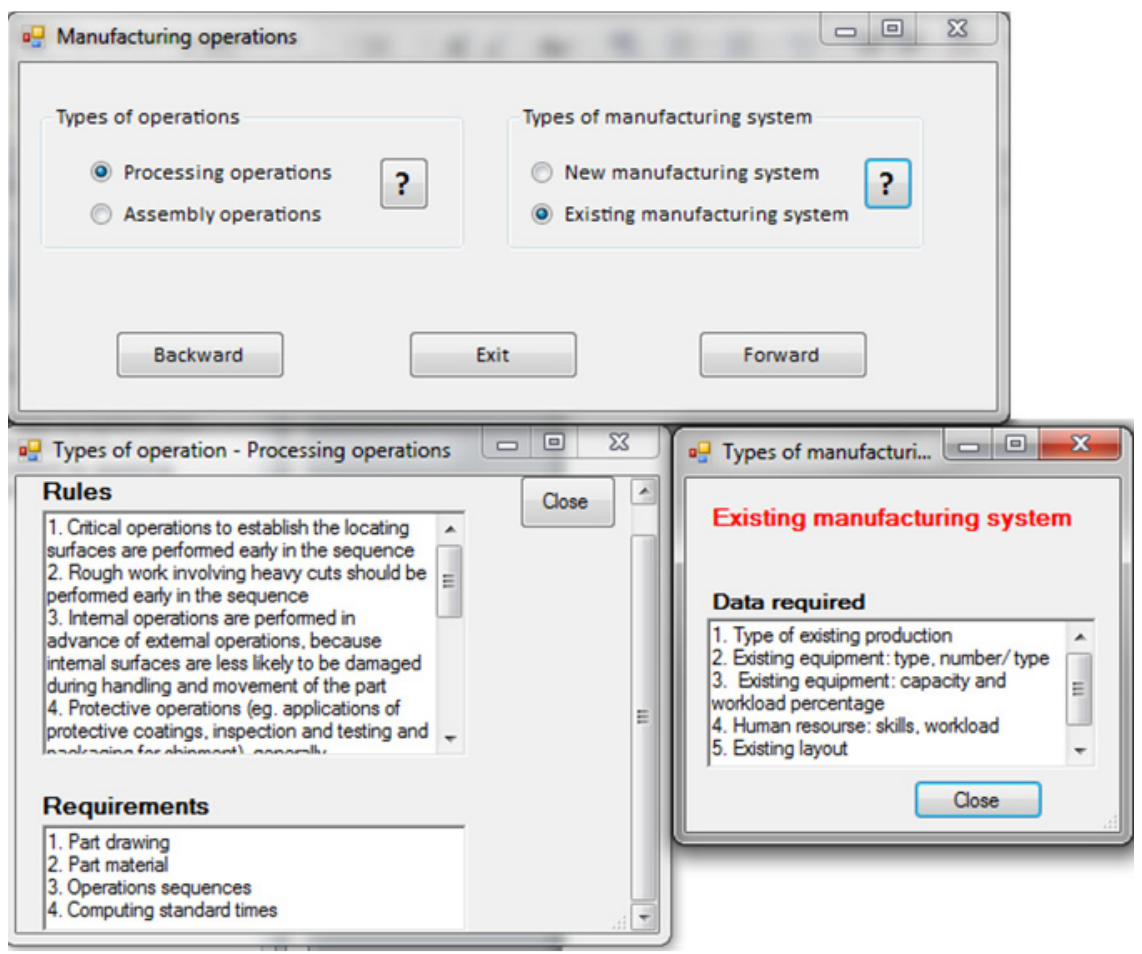

Fig. 3. Defining processing system.

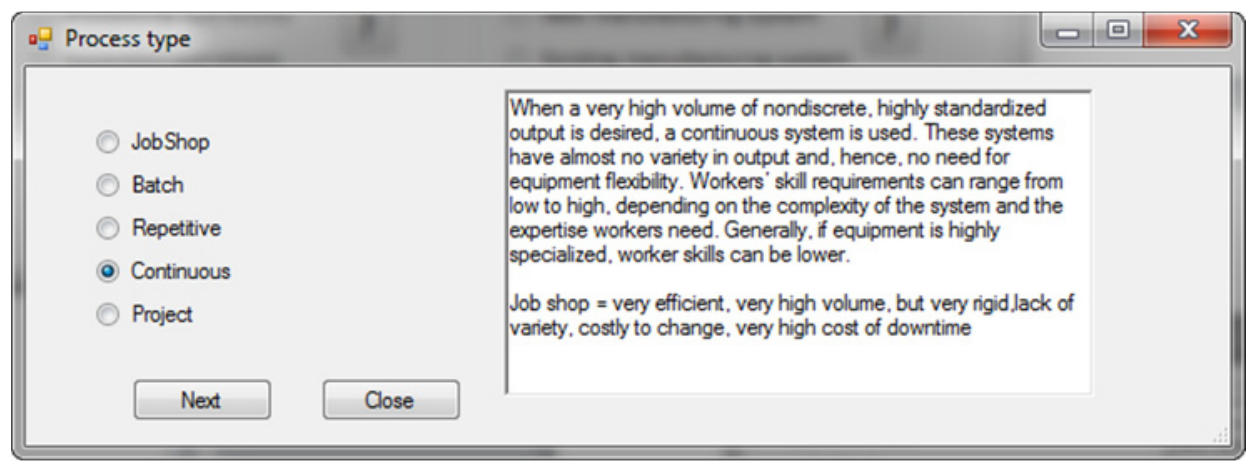

Fig. 4. Process type selection.

\section{Conclusions and results}

CADOProSys - process selection is able to generate de route sheet, to compute materials and equipment required quantity and, for existing system to determine if the desired lot size is able to be manufactured considering the data from the system. To show the results, in the following is considering the following situation: to implement, in an existing manufacturing system, the flow of linear guides. The product is manufacturing together with other 18 products (lot size is 760 pieces/ month). Manufacturing flow contains: complex cutting, treating, washing, control and assembly. For the complex cutting firm uses two CNC machines. Data are introduced according to interface from Figure 5. 


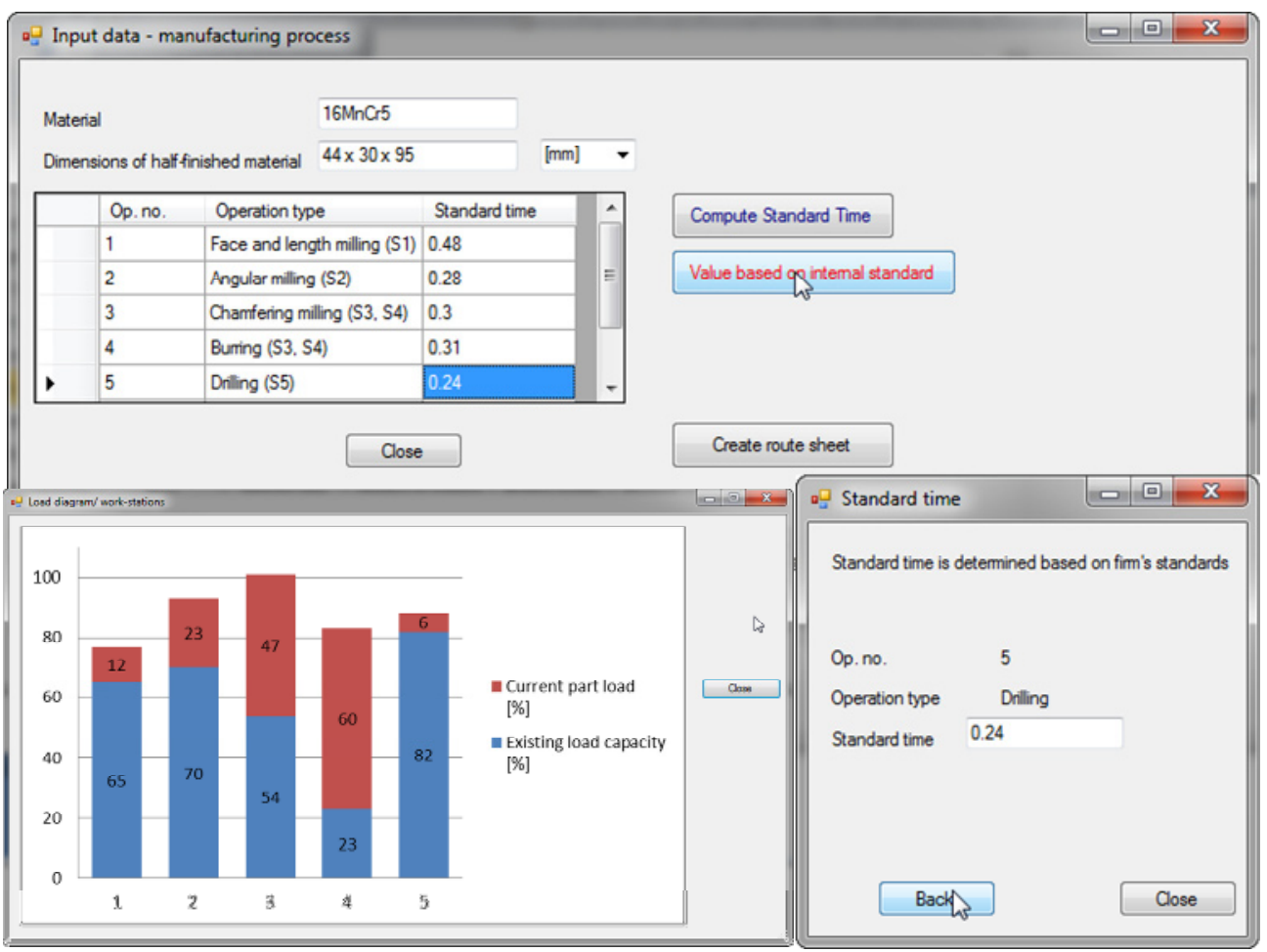

Fig. 5. Input data.

Based on these data, it may be generated route sheet for each part of the final product, which is an Excel file, particularized for the firm and product. Using the data it can be computed load for each work-station (values and graphical representation - Figure 5).

CADOProSys is educational software, designed, as a main purpose, to change the students' focus: from calculus (that is automatically done by the software) to understand the essence of the manufacturing system design. Using CADOProSys students will be able to feel better the problems of manufacturing systems, to follow the design steps, to understand interconnections between requirements of such design, essentially to answer to "why?", "when?", "what?" and "what for?" questions regarding manufacturing systems design.

\section{References}

1. Software Advice. http://www.softwareadvice.com/manufacturing

2. Digital Manufacturing Solutions. DELMIA. http://4dmsco.com/

3. Siemens Tecnomatix www.plm.automation.siemens.com/en_us/products/tecnomatix/

4. W. Stevenson, Operations Management (McGraw-Hill Irwin, 2012)

5. M. Groover, Fundamentals of Modern Manufacturing (John Wiley \& Sons, Inc., 2010)

6. N. Slack, A. Brandon-Jones, R. Johnston, Operations Management (Pearson, 2013)

7. A. Garcia-Diaz, J. McGregor Smith, Facilities Planning and Design (Pearson, 2008)

8. E. Klimczak. Design for Software: A Playbook for Developers. (Wiley P.H., 2013)

9. P. Tchounikine. Computer science and educational software design (Springer, 2011)

10. D. Unger, S. Eppinger. CJEN, 22, 689 (2011)

11. D. Cochran, A. Chu, M.U. Jafri, Z. Bi. JIII, 2, 65 (2016)

12. A. Thecle, Y. Benama, N. Perry. Adv. PMS, 440, 1 (2014) 